\title{
DAMPAK BULLYING TERHADAP PESERTA DIDIK SMA
}

\author{
${ }^{1}$ Dinda Aulia, ${ }^{2}$ Rosalinda Nababan \\ Dr. Junita Friska,S.Pd., M.Pd \\ Universitas Negeri Medan
}

\begin{abstract}
ABSTRAK
Bullying (perundungan) adalah perilaku kekerasan yang agresif dan menimbulkan permusuhan antara dua pihak (pelaku dan korban), serta berulang sebagai perilaku yang negatif sehingga terjadi ketidakseimbangan kekuatan antar pihak tersebut. Bullying dapat terjadi di berbagai kalangan, salah satunya remaja di sekolah. Secara global, diperkirakan 246 juta anak-anak dan remaja menjadi menjadi korban dengan berbagai bentuk tindakan setiap tahunnya salah satunya Sekolah Menengah Atas (SMA) mengalami bullying (24,08\% pada laki-laki dan $17.40 \%$ pada perempuan). Penelitian ini bertujuan untuk memperlihatkan hubungan antara bullying dengan mental pada peserta didik SMA. Adapun metode yang digunakan yaitu penelitian kualitatif dengan menggunakan pendekatan fenomenologis. Hasil yang didapatkan dari penelitian yaitu tindakan bully masih marak terjadi dikalangan siswa khususnya siswa SMA. Tindakan bully ini sangat mempengaruhi mental siswa yang menjadi korban, banyak penelitian menyebutkan bhawa sebagian besar siswa yang melakukan tindakan percobaan bunuh diri adalah mereka yang menjadi korban tindakan bully.
\end{abstract}

Kata kunci: Bullying, Peserta didik, SMA

\section{ABSTRACT}

Bullying is violent behavior that is aggressive and creates hostility between two parties (perpetrators and victims), and is repeated as negative behavior resulting in an imbalance of power between the parties. Bullying can occur in various circles, one of which is teenagers at school. Globally, it is estimated that 246 million children and adolescents become victims of various forms of action each year, one of which is high school (SMA) experiencing bullying (24.08\% for boys and $17.40 \%$ for girls). shows the relationship between bullying and mentality in high school students. The method used is qualitative research using a phenomenological approach. The results obtained from the study are that bullying is still prevalent among students, especially high school students. This bullying act greatly affects the mentality of students who are victims, many studies say that most students who attempt suicide are those who are victims of bullying.

Key words: Bullying, Students, Senior High School 


\section{PENDAHULUAN}

Perilaku bullying di Indonesia belum mendapatkan perhatian resmi dari pemerintah, sebagian besar sekolah maupun perguruan tinggi belum memberikan kebijakan prosedur mengatasi kasus bullying, padahal menurut hasil survei Plan Indonesia dan penelitian yang di lakukan oleh yayasan SEJIWA di 3 kota besar di Indonesia yaitu Jakarta, Yogyakarta dan Surabaya pada tahun 2008 lalu, 66,1\% pelajar SMP dan SMA 67,9\% menyatakan tindakan bullying pernah terjadi di sekolah tersebut. Menurut Simbolon (2005), survei yang di lakukan Departemen pendidikan menyebutkan bahwa terdapat 24.898 tindakan bullying di sekolah, dari jumlah tersebut 12.307 khasus terjadi di perguruan tinggi swasta, pada tahun 2006 di indonesia terdapat 247 kasus kekerasan fisik (29 kasus terjadi di sekolah), 426 kasus kekerasan seksual (67 kasus di sekolah) dan 561 kekerasan psikis (96 kasus terjadi di sekolah). Muhammad (2009) menyebutkan Bahkan pada bulan januari sampai juni 2007, Komisi perlindungan anak mendapat laporan 326 kasus bullying yang terjadi di wilayah Jabodetabek, angka ini menunjukan telah terjadi peningkatan kasus bullying yang sangat besar.

Komisi Perlindungan Anak Indonesia (KPAI, 2016) mengidentifikasi kasus yang mengacu pada klaster perlindungan anak dari tahun 2011-2016. KPAI menyebutkan angka korban bullying di atas 50 sejak 2011-2016. Terakhir, pada tahun 2016 angka korban mencapai 81. Angka tersebut ditemukan pada kasus bullying yang terjadi di lingkungan sekolah. Untuk angka pelaku bullying, KPAI (2016) menemukan jumlah di atas 40 orang. Pada tahun 2016, jumlah pelaku bullying di lingkungan sekolah mengalami kenaikan menjadi 93 orang.

Besarnya angka pelaku bullying dibandingkan angka korban bullying merupakan indikator bahwa bullying dilakukan oleh beberapa orang dengan korban yang tidak sebanding dengan kelompok yang melakukan bullying. Bullying tidak sekedar mencermati pelaku bullying dan korbannya Schott (2014). Fenomena bullying tidak hanya dilihat dari sudut pandang individu pelaku dan korban, tetapi hal itu lebih menitikberatkan pada aspek sosial yang melatarbelakangi fenomena tersebut terjadi (Schott, 2014). Iklim sosial sering menjadi indikator beberapa fenomena yang muncul di masyarakat. Termasuk bullying, korban mengalami kekerasan karena dianggap di luar lingkaran sosial pelaku bullying.

Karena poin bullying terletak pada fenomena sosial, Olweus (1999) mendefinisikan bullying sebagai masalah psikososial dengan menghina dan merendahkan orang lain secara berulangulang dengan dampak negatif terhadap pelaku dan korban bullying di mana pelaku mempunyai kekuatan yang lebih dibandingkan korban. Mengacu pada definisi bullying menurut Olweus (1999), Schott (2014) memetakan tiga poin yang terdapat pada definisi tersebut. Diantaranya adalah terkait bullying sebagai tindakan agresi individu, bullying sebagai kekerasan sosial, dan bullying sebagai dinamika kelompok disfungsional Schott (2014). Bullying merupakan tindakan agresif, baik secara fisik maupun verbal, yang dilakukan oleh individu (Schott, 2014). Tindakan tersebut dilakukan secara berulang kali, dan terdapat perbedaan kekuatan antara pelaku dan korban (Schott, 2014). Perbedaan kekuatan dalam hal ini merujuk pada 
sebuah persepsi terhadap kapasitas fisik dan mental (Schott, 2014). Selain itu, perbedaan kekuatan juga terdapat pada jumlah pelaku dan korban (Schott, 2014).

Puspitaningrum

(2011),

mengemukakan korban bullying dapat mengalami efek prilaku dalam jangka panjang dan janga pendek. Dalam jangka waktu pendek, mereka akan merasa depresi, kehilangan keinginan untuk sekolah dan akhirnya menghindari sekolah itu sendiri, sedangkan jangka panjang adalah adanya kecendrungan menganggap dirinya rendah dalam jangka waku yang cukup lama. Akibatnya korban bullying sulit untuk menyesuaikan diri pada suatu lingkungan yang buruk, bahkan cenderung bersikap emosi negatif mudah marah, tidak nyaman dengan lingkungan sekitarnya sehingga tidak ada kemampuan untuk menghadapi Tindakan bullying sering terjadi di sekolahsekolah terutama pada jenjang tingkat SMA atau remaja awal, dimana banyak terjadi tindakan bullying seperti kekerasan verbal, seksual bahkan fisik, karena pada masa ini remaja mengalami puncak emosionalitasnya yang merupakan perkembangan emosi yang tinggi, remaja tidak hanya mengejar kepuasan fisik saja tetapi meningkat kepada tekanan psikologis (rasa di terima dan di hargai) (Nindya dan Margaretha, 2012).

\section{TINJAUAN PUSTAKA}

\section{Pengertian Bullying}

Secara umum bullying merupakan perilaku negatif seseorang atau lebih kepada korban yang dilakukan secara berulangulang, terjadi dari waktu ke waktu dengan cara menyakiti fisik maupun mental (Prasetyo, 2011). Menurut Djuwita (2010)
Bullying sendiri merupakan perbuatan agresi atau manipulasi yang disadari dan bertujuan, yang dilakukan oleh satu atau lebih orang terhadap satu atau sekelompok orang lainnya. Dimana pelaku sengaja menyakiti orang lain, baik secara fisik maupun psikologis untuk mendapatkan kepuasan karena merasa lebih berkuasa, sehingga target biasanya adalah orang yang lebih lemah dan tidak cukup memiliki dukungan sosial untuk melawan (Sullivan, 2010), yang melibatkan kekuatan dan kekuasaan yang tidak seimbang, sehingga korbannya berada dalam keadaan tidak mampu mempertahankan diri secara efektif untuk melawan tindakan negatif yang diterima korban (Krahe, 2005). Sehingga bullying merupakan problem yang dampaknya harus ditanggung oleh semua pihak (Priyatna, 2010) baik itu pelaku, korban, ataupun dia yang menyaksikan tindakan bullying tersebut.

\section{Menurut Olweus}

mendefinisikan bullying sebagai masalah psikososial dengan menghina dan merendahkan orang lain secara berulangulang dengan dampak negatif terhadap pelaku dan korban bullying di mana pelaku mempunyai kekuatan yang lebih dibandingkan korban.

\section{Faktor Internal dan Faktor Eksternal yang Menyebabkan Bullying}

Bullying yang marak terjadi dilatarbelakangi oleh beberapa faktor. Rosen et al. (2017) menjelaskan beberapa faktor yang menyebabkan bullying dalam bukunya, diantaranya adalah faktor internal dan eksternal. Faktor internal yang menyebabkan bullying adalah faktor temperamental dan faktor psikologi terhadap intensitas melakukan tindakan agresi (Rosen et al., 2017). Pelaku bersikap impulsif dan 
minimnya kemampuan regulasi diri (Rosen et al., 2017). Apabila mereka melakukan tindakan kekerasan, mereka tidak merasa bersalah ataupun berempati terhadap korban. Demikian, individu yang melakukan tindakan bullying memiliki kemampuan sosial yang rendah (Rosen et al., 2017).

Selanjutnya, Menesini et al. (2013) meneliti terkait aspek moral pada perilaku dan tindakan bullying. Penelitian bertujuan menguji peran perilaku tidak bermoral terhadap keterlibatan dalam bullying. Hasil penelitian menunjukkan bahwa moral berperan pada tindakan pelaku bullying.

Faktor eksternal yang mengakibatkan tindakan bullying ialah pola asuh orang tua (Lereya et al., 2013). Hal itu meliputi meliputi bagaimana orang tua melakukan kekerasan kepada mereka dan pola asuh dengan kontrol yang rendah dengan kehangatan yang tinggi,mengamati perilaku dan tindakan kekerasan pengamatan termasuk bagaimana orang tua melakukan agresi terhadap orang lain atau ketika mereka melihat orang lain melakukan tindakan tersebut kemudian mereka melakukan tindakan agresi yang mereka amati, pengaruh teman terbentuk ketika lingkaran pertemanan umumnya menyesuaikan dengan karakter yang sama sehingga mereka akan menjalin pertemanan dengan teman dengan individu agresif yang kemudian berimplikasi terhadap perilaku anti-sosial, pemaparan informasi melalui media, film yang menunjukkan tindakan agresif juga menjadi model untuk melakukan tindakan bullying, dan mendengarkan lagu dengan lirik yang mengindikasikan terhadap tindakan agresif, serta bermain video games (Rosen et al., 2017). Demikian, lingkungan sosial merupakan faktor yang mendasari individu dalam melakukan tindakan kekerasan.

\section{Bentuk Perilaku Bullying terhadap Peserta Didik di SMA}

Secara umum terdapat tiga bentuk perilaku bullying yang terjadi terhadap peserta didik di sekolah. Tiga bentuk perilaku bullying yang dimaksud tersebut adalah:

1). bentuk fisik,

2). bentuk verbal,

3). bentuk psikologis.

Tindakan bullying dapat dibagi menjadi tiga kategori, yaitu bullying fisik, bullying verbal dan bullying mental atau psikologis (Nusantara, 2008). Bullying fisik terjadi ketika seseorang secara fisik dirugikan melalui tindakan, bullying verbal adalah bullying yang dilakukan dengan mengancam, melakukan panggilan bernada seksual, dan menyebarkan desas desus palsu atau jahat serta bullying mental atau psikologi adalah tindakan yang dilakukan dengan mengabaikan orang lain, mengisolasi dan membuat peserta didik lain tidak menyukai seseorang.

\section{Dampak Bullying terhadap Peserta Didik di SMA}

Dampak tindakan bullying tidak hanya pada korban, tetapi dampak tersebut juga mengenai pelaku bullying dan korbanpelaku bullying. Penelitian yang dilakukan oleh Skrzypiec et al. (2012) menghasilkan pemahaman bahwa dampak negatif bullying dirasakan oleh korban, pelaku, korbanpelaku bullying. Penelitian tersebut menggunakan alat ukur Strengths and Difficulties Questionnaire (SDQ, Goodman, 1997 dalam Skrzypiec et al., 2012). Korban, pelaku, korban-pelaku bullying mengalami 
gangguan kesehatan mental (Skrzypiec et al., 2012).

Sebagaimana telah disebutkan
sebelumnya bahwa pelaku bullying
mempunyai intensitas empati yang minim dalam fenomena interaksi sosial. Skrzypiec et al. (2012) menyebutkan bahwa mereka mengalami permasalahan perilaku abnormal, hiperaktif, dan pro-sosial ketika terlibat dalam proses interaksi sosial. Baik empati maupun perilaku abnormal, perilaku hiperaktif, dan pro-sosial sangat berkaitan dengan respon pelaku ketika dirinya terlibat dengan lingkungan sosial sekitar. Berbeda dengan korban-pelaku, tingkat gangguan kesehatan mental mereka lebih besar dibandingkan pelaku dan korban bullying.

Mereka adalah individu yang melakukan tindakan bullying, namun mereka juga menjadi korban bullying (Slee \& Skrzypiec, 2016). Mereka mengalami permasalahan pro-sosial, hiperaktif, dan perilaku (Skrzypiec et al., 2012). Untuk korban bullying, penelitian Skrzypiec et al. (2012) menjelaskan bahwa mereka berada pada rating antara pelaku dan korban-pelaku bullying. Mereka mempunyai masalah dengan kesehatan mental, terutama gejala emosional (Skrzypiec et al., 2012). Hal yang sering ditemukan adalah mereka sering terisolasi secara sosial, tidak mempunyai teman dekat atau sahabat, dan tidak memiliki hubungan baik dengan orang tua (Rosen et al., 2017).

Korban bullying juga mengalami kekerasan fisik, untuk bullying yang bersifat kekerasan secara fisik. Tindakan kekerasan secara fisik dan verbal yang mereka terima sering menjadi faktor trauma untuk jangka pendek dan jangka panjang. Trauma memengaruhi terhadap penyesuaian diri dengan lingkungan, yaitu dalam hal ini adalah lingkungan sekolah (Modecki et al., 2014). Bahkan, penelitian yang dilakukan oleh Cornell et al. (2013) menemukan bahwa bullying merupakan prediktor untuk tingkat prestasi akademik dan putus sekolah siswa Sekolah Menengah Atas (SMA).

Apabila penelitian Cornell et al. (2013) dilakukan pada siswa SMA, partisipan penelitian Takizawa et al. (2014) berusia 7 , $11,16,23,33,42,45$, dan 50 tahun yang berjalan selama 50 tahun sejak tahun 1958. Penelitian tersebut menyimpulkan bahwa bullying yang terjadi pada anak-anak mengakibatkan tingginya tingkat depresi, kecemasan, dan bunuh diri ketika dewasa (Takizawa et al., 2014). Tidak hanya itu, mereka bahkan mengalami permasalahan dalam hubungan sosial, kondisi ekonomi yang memburuk, dan rendahnya well-being ketika menginjak usia 50 tahun (Takizawa et al., 2014; Slee \& Skrzypiec, 2016). Demikian, bullying berdampak pada rendahnya tingkat hubungan sosial korban, kesehatan mental dan fisik, dan persoalan ekonomi (Takizawa et al., 2014).

\section{Prevensi dan Intervensi terhadap Fenomena Bullying di Sekolah}

Pengembangan

program pencegahan dan intervensi yang efektif dalam mengurangi perilaku bullying, diperlukan suatu pendekatan yang komprehensif mencakup seluruh sistem, termasuk orang tua, teman sebaya, pendidik, konselor sekolah, administrator sekolah, dan warga sekolah.

Pertama, sekolah harus melakukan asesmen (Kowalski \& Morgan, 2017). Dalam hal ini, sekolah dapat memberikan kuesioner singkat kepada siswa untuk mengetahui kecenderungan siapa yang mengalami bullying. Siswa dari jenis 
kelamin dan tingkat kelas tertentu dapat diidentifikasi sebagai pelaku dan / atau korban. Selain itu, "upaya efektif untuk mencegah dan mengatasi bullying membutuhkan perhatian terhadap faktorfaktor individu yang dapat berkontribusi pada kemungkinan bullying, seperti karakteristik, dan tantangan anak-anak dan remaja, serta faktor dalam ekologi sosial individu, termasuk keluarga anak, sekolah, kelompok sebaya, dan komunitas" (Limber et al., 2016). Setiap anak memiliki pengalaman sosial yang unik, lebih lanjut menandakan kebutuhan untuk perhatian individual. Antara lain, keterlibatan siswa dalam jenis-jenis bullying lainnya (sebagai pelaku, maupun korban), status sosial di sekolah, tingkat kelas, dan sebagainya adalah variabel yang relevan.

Titik awal yang baik untuk diskusi mengenai bullying dan kesejahteraan digital adalah di dalam kelas. Program pencegahan dan intervensi terhadap bullying yang paling efektif bukanlah yang berhasil mengundang seorang pembicara yang berpengetahuan luas untuk sebuah pertemuan para siswa tentang bullying.

Rancangan seperti ini sering digunakan di sekolah-sekolah, tetapi tidak secara efektif memberikan perhatian dan memfokuskan di tiap tingkatan kelas yang ada. Meskipun informasi yang diberikan oleh pembicara itu bermanfaat, program yang paling efektif adalah program yang waktu kelasnya dikhususkan untuk diskusi dan kegiatan tentang bullying (Limber, Kowalski, \& Agatston, 2014a). Situasi dapat disajikan kepada siswa dan siswa diminta untuk mengidentifikasi apakah situasinya tersebut mengandung unsur bullying atau tidak, Dalam diskusi kelas ini, siswa dapat diberikan pertanyaan mengenai apa yang mereka ketahui tentang kebijakan sekolah tentang bullying, bagaimana siswa melaporkan bullying, dan bagaimana mereka seharusnya menanggapi dengan baik dalam situasi bullying yang mereka terima. Ini dapat memberikan siswa kesempatan untuk terlibat dalam dialog terbuka di lingkungan yang aman. Selain itu, dapat membantu para siswa untuk mengenali perilaku bullying yang sebenarnya.

Orang tua sering kali diabaikan dan tidak diikutsertakan dalam program penanggulangan terhadap bullying seperti ini, seharusnya mereka perlu terlibat aktif (Simon \& Olson, 2014). Siswa yang melihat bahwa orang tua mereka secara aktif terlibat dalam upaya penanggulangan bullying di sekolah mereka, akan lebih cenderung mendekati orang tua mereka sebagai titik kontak pertama dalam peristiwa yang terjadi di dalam bullying itu sendiri.

\section{METODE PENELITIAN}

Penelitian ini menggunakan jenis penelitian kualitatif dengan menggunakan pendekatan fenomenologis. Pendekatan fenomenologi merupakan pandangan berfikir yang berfokus pada pengalamanpengalaman subjektif, peneliti dalam pandangan fenomenologi berusaha memahami arti peristiwa dan kaitannya terhadap orang yang berada dalam situasi tertentu (Moleong, 2014). Penelitian kualitatif ini dipilih karena lebih sensitif dan adaptif terhadap peran dan berbagai pengaruh yang timbul, disamping itu peneliti akan mencoba menggali, mengeksplorasi atau mengembangkan pengetahuan bagaimana pengetahuan yang diketahui.

Selain itu,penelitian tersebut juga menggunakan metode kajian literatur. 
Kajian literatur melibatkan literatur yang diperoleh secara daring, yang terdiri dari artikel jurnal/penelitian dan buku. Analisis terhadap literatur bertujuan untuk menjawab lima pertanyaan penelitian yang telah dirumuskan sebelumnya. Hal itu dimaksudkan untuk mengetahui isu terkini dan perkembangan teori bullying dan literature tersebut merupakan pokok teori dalam kajian bullying.

\section{HASIL DAN PEMBAHASAN}

Berdasarkan pengisian angket google form yang kami terima,adapun hasilnya sebagai berikut:

Dari pertanyaan pertama ini diperoleh hasil $80 \%$ siswa pernah dibully yang artinya 16 siswa pernah dibully dan 4 lainnya tidak. Hal ini berarti bahwa pembullyan di kalangan siswa tingkat SMA masih marak bahkan tidak memandang perempuan ataupun laki-laki.

Dari pertanyaan kedua ini $20 \%$ siswa menjawab Ya, artinya 4 dari 20 responden pernah melakukan tindak bullying dan 16 lainnya tidak yang artinya 16 siswa tersebut adalah korban dari tindakan bully. Sangat disayangkan bahwa siswa-siswa tersebut melakukan tindakan bully, padahal pada dasarnya tugas dan kewajiban mereka adalah belajar. Namun yang paling memprihatinkan adalah banyak penelitian yang menyatakan bahwa sebagian besar mereka yang membully adalah mereka yang memiliki kekurangan dalam pergaulan dimana mereka butuh reaksi dari si korban agar orang lain yang menyaksikan hal tersebut menjadikan hiburan.

Pertanyaan kegita ini jawaban yang kami terima beragam mulai dari mengejak, menghina fisik, dituduh melakukan hal yang dilakukan, dan merendahkan diri. Namun dari 20 responden banyak yang menjawab mengejek ataupun menghina, baik itu fisik atau hal lainnya. Penelitian mengatakan bahwa bentuk bullying yang dilakukan siswa pada umumnya sebatas mengejek ataupun menghina, namun hal tersebut tetap memberi dampak bagi si korban baiik itu secara fisik ataupun mental. Hal ini berarti tindakan-tindakan yang dilakukan siswa ini menggambarkan bahwa siswa yang mrmbully tersebut merasa bahwa dirinya lebih baik daripada korban bullyannya, terlihat dari berbagai jawaban responden. Hal tersebut tentu saja tidak dapat dibiarkan terus menerus, mungkin bagi siswa yang membully itu suatu hal bercandaan atau sekedar teguran tapi bagi si korban jika hal tersebut seringkali dilakukan dan siswa lain yang melihat atau mendengar ikut serta ataupun menertawakan, maka itu menjadi suatu bentuk tindakan bully.

Dari pertanyaan keempat ini diperoleh hasil $75 \%$ persen siswa menjawab Ya, artinya 15 dari 20 responden menjawab bahwa orang yang melakukan tindakan bully ataupun orang yang membully mereka adalah teman dekat atau orang yang mereka kenal dan 5 siswa lainnya menjawab tidak. Hal ini menunjukkan bahwa siswa yang membully ataupun dibully adalah mereka yang masih teman dekatnya, bisa saja teman satu kelas atau teman sekolah ataupun teman sepermainan.

Pertanyaan kelima ini diperoleh jawaban yang beragam dari 20 responden. Rata-rata jawaban dari responden yaitu mereka tidak mengetahui pasti alasan mengapa melakukan tindakan bully ataupun dibully. Namun yang menjadi menarik adalah kebanyakan siswa 
melakukan tindakan bully karna emosi yang tidak dapat dikontrol. Hal tersebut mungkin saja terjadi pada siswa yang memiliki masalah yang tidak dapat diselesaikan ataupun siswa yang mungkin merasa tersaingi ataupun iri.

Dari berbagai bentuk jawaban responden dapat disimpulkan bahwa tindakan bully ini bisa saja terjadi secara disengaja atapun tidak, dan mereka yang melakukan secara sengaja merasa bahwa dengan membully mereka dapat melampiaskan rasa kekesalan mereka ataupun menghibur diri mereka. Sedangkan untuk yang tidak disengaja, mungkin tindakan tersebut masih batas wajar bagi mereka yang membully, namun bagi siswa yang menerima tindakan bully tersebut merasa itu salah dan tidak pantas dilakukan sebagai teman dekat.

Pertanyaan keenam ini juga diperoleh jawaban responden yang beragam, dan rata-rata responden menjawab diam ataupun tidak melawan. Namun ada beberapa responden yang menjawab melawan dan juga bersyukur. Hal ini membuktikan bahwa mereka yang menerima tindakan bully ini merasa bahwa apa yang mereka terima tidak pantas untuk dilawan yang artinya mereka diam saja jika dibully. Namun hal ini akan membuat mereka yang membully akan melakukan tindakan bully tersebut secara terus menerus. Melawan ataupun membalas mereka yang membully juga perlu, namun dalam batas wajar dan tidak menimbulkan keributan dan alangkah lebih baik jika mereka yang melakukan tindakan bully dan mereka sebagai korban membicarakan ataupun mendiskusikan secara baik-baik apa tujuan ataupun motivasi siswa tersebut melakukan bully.

Dari pertanyaan ketujuh ini banyak responden menjawab Ya, artinya tindakan bully yang mereka lakukan ataupun terima mempengaruhi mental mereka. Sebagi siswa ini sangat berpengaruh bagi kegiatan belajar mereka. Namun tak sedikit siswa juga merasa bahwa tindakan bully tersebut tidak mempengaruhi mental mereka. Penelitian menyatakan bahwa banyak siswa SMA melakukan tindakan ingin bunuh diri karena merasa tertekan sebagi korban bully temannya sendiri. Hal ini membuktikaj bahwa tindakan bully tersebut sanagt berdampak bagi mental siswa. Tak banyak yang tahu bahwa mereka yang dibully mungkin merasa baik-baik saja di depan teman-teman lainnya namun bagi korban hal tersebut sangat mengusik mentalnya karena sudah sakit hati dan terus kepikiran dan tidak bisa melakukan perlawanan sehingga banyak siswa khususnya siswa SMA banyak melakukan tindakan percobaan bunuh diri.

Sementara untuk pertanyaan kedelapan, didapatkan hasil data tersebut diperoleh hasil $75 \%$ siswa menjawab tidak, artinya 15 dari 20 siswa tidak memberitahu kepada orangtua mereka tentang tindakan bully yang mereka lakukan ataupun terima.

Sedangkan pertanyaan kesembilan, hasil yang diperoleh, 5 dari 20 siswa yang menjawab Ya mengatakan bahwa orangtua mereka memberikan mereka saran ataupun arahan dan bahkan diam saja. Hal ini membuktikan bahwa masih banyak orangtua siswa yang tahu jika anakanya pernah dibully ataupun membully namun tetap diam. Sebagai orangtua, harusnya memperhatikan anaknya yang menjadi korban dan memberi teguran ataupun hukuman jika anaknya melakukan tindakan bully karena 
hal tersebut salah. Banyak para orangtua menganggap bahwa tindakan bully yang dilakukan anaknya masih batas wajar ataupun hanya sebagai bahan candaan, namun mereka tidak tahu bahwa yang dilakukan anaknya tersebut salah karena mempengaruhi mental anak lain yang menjadi korban.

Terakhir untuk pertanyaan kesepuluh, data diperoleh hasil bahwa 85\% siswa menjawab Ya, artinya 17 siswa mengatakan bahwa tindakan bully yang mereka lakukan ataupun terima bisa dijadikan motivasi. Jika tindakan bully masih batas wajar mungkin bisa memberi motivasi yang positif, misalnya siswa yang memiliki berat badan yang berlebih dibully oleh temannya maka ia merasa termotivasi untuk menurunkan berat badannya dan bagi siswa yang membully juga akan merasa bahwa tindakan yang dilakukannya memberi perubahan bagi siswa yang dibullynya.

\section{KESIMPULAN}

Dari hasil pengataman yang kami lakukan yaitu berupa pengisian kuisioner melalui media google form dapat kami simpulkan bahwa tindakan bully masih marak terjadi dikalangan siswa khususnya siswa SMA. Target ataupun korban dari tindakan bully juga tidak memandang baik itu perempuan ataupun laki-laki dan pada umumnya adalah orang yang mereka kenal dan bahkan teman dekat mereka sendiri. Bentuk tindakan yang dilakukan juga beragam salah satunya menghina fisik dan merendahkan diri serta tujuan ataupun alasan mereka juga beragam baik itu hanya sebagai bahan camdaan ataupun sekedar hiburan. Tindakan bully ini sangat mempengaruhi mental siswa yang menjadi korban, banyak penelitian menyebutkan bhawa sebagian besar siswa yang melakukan tindakan percobaan bunuh diri adalah mereka yang menjadi korban tindakan bully. Sangat disayangkan jika tindakan bully ini masih saja dianggap remeh baik itu bagi siswa itu sendiri atapun orangtua. Namun tak sedikit dengan adanya tindakan bully ini dapat dijadikan motivasi bagi siswa yang menerimanya ataupun yang melakukannya.

\section{SARAN}

Tindakan bully bukan merupakan tindakan wajar jika mempengaruhi mental siswa yang menerimanya. Sebagai siswa haruslah memperhatikan apakah tindakan yang dilakukan tersebut baik dilakukan atau tidak agar tidak terjadinya tindakan bully. Sebagai guru dan orangtua hendaknya memperhatikan perilaku ataupun tindakan anak didiknya baik disekolah ataupun dirumah, karena hanya orangtua yang dapat memberikan arahan dan teguran bagi anak didiknya.

\section{DAFTAR PUSTAKA}

Kusumasari,dkk.(2019). Bullying di Sekolah: Pengertian, Dampak, Pembagian dan Cara Menanggulanginya. Pedagogia Jurnal Ilmu Pendidikan. 17 (01) :55-66.

Link:http://ejournal.upi.edu/index.php/peda gogia

Amnda,Viola.,dkk.(2020). Bentuk Dan Dampak Perilaku Bullying Terhadap Peserta Didik. Jurnal Kepemimpinan Dan Kepengurusan Sekolah. 5(1):19-32.

Link:https://ejurnal.stkippessel.ac.id/index.php/kp 
Darwin., Mubin.F., Hidayati.E.( 2014).

Pengalaman Siswa Yang

Mendapatkan Bullying Di Sma N

15 Semarang . Jurnal Keperawatan

Komunitas . 2 (1): 1-6.

Prasetyo,Ahmad.(2011).Bullying di

Sekolah dan Dampaknya bagi

Masa Depan Anak.Jurnal

Pendidikan Islam. 4(1):19-26. 
